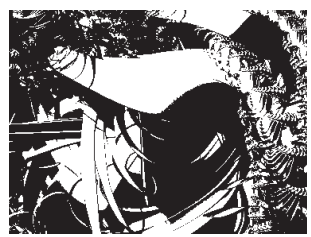

\title{
INSTITUTIONALISED CHRISTIANITY AND THE QUESTION OF GENDER HIERARCHY
}

Nadja FURLAN

Science and Research Centre, Koper

UDK: 261.627

Pregledni rad

Primljeno: 6. 4. 2009.

The paper develops, from a feminist point of view, the issues of emergence and presence of patriarchal principles, gender hierarchy and unequal distribution of power between the genders within Christianity. First of all, it poses the question as to whether patriarchal supremacy is proper to and ordained by the Christian tradition or has developed and strengthened throughout the process of the institutionalisation of Christianity. The western world, shaped under the influence of Christianity, has been recording an increased number of critical questions concerning the issue of gender hierarchy within individual Christian Churches, the Catholic Church in particular. The patriarchal character of the Church order is called into question and put under a microscope. With the help of a scientific methodology that employs the hermeneutic key of feminist theology the paper endeavours to trace the origins of patriarchal androcentrism and unequal appreciation of the two genders. The results of the discussion corroborate the hypothesis that during the process of institutionalisation the Catholic Church adopted the patriarchal denotation of the culture in which it developed, and confirm the theory that Christianity in its doctrine sets a strong imperative of gender equality, grounded both in the person of Jesus Christ and his attitude towards women as well as in the Bible.

Keywords: gender hierarchy, gender equality and the Bible, institutionalisation of Christianity, patriarchalisation of Church and Christianity, feminist theology

Nadja Furlan, Science and Research Centre of Koper, University of Primorska, Garibaldijeva 1, 6000 Koper, Slovenia. E-mail: nadja.furlan@zrs.upr.si 
Some critiques, feminist in particular, claim that all religions set women in a subordinate position, depriving them of rights and dignity. Reference is made to the idea of religions being the key that in individual socio-political structures opens the door to a patriarchal oriented mentality (Franzmann, 2000, 60). Feminist theologian E. Sorge, for instance, wonders if there has ever been a religion favourable to women (Sorge, 1988, 22). Similarly, many feminists reproach Christianity with supporting and spreading 'the ideology of male superiority' instead of promoting the aspiration of gender equality. They refer to the fact that, in the past as well as in the present global world, the Church ${ }^{1}$ has played the most important role in the shaping and preservation of cultural and social patterns of everyday life, and has been an institutional vehicle of religious substantiation of earthly life, representing as such an inseparable component in the formation of the existing system of interpersonal relationships.

Gender discrimination, whether a product of nature or society, results in an unequal distribution of power. In fact, emphasising the advantages or deficiencies of a determinate gender or gender roles encourages a precedence-oriented hierarchy. In this sense, gender discrimination implies advantages for one gender and disadvantages for the other, although it is based on an exaggerated and quite relative generalisation. The result is an unequal distribution of power, which translates into a polarisation or supremacy in favour of one of the antipodes, in this case the male gender. The sociology of gender defines cultures regulated this way as sexist, androcentric or male-centric. This type of system in fact consigns the woman to the background, treating her as less important, second-class and subordinate to the man. This is evident in all spheres of activity and life, with all key social institutions ensuring the reproduction of the entire social division of labour, of social roles and interpersonal relationships. The main power and characteristic of sexism is in its self-evidence, which is an inseparable component of everyday-life behaviour patterns. The issue of gender equality is becoming increasingly topical and present even in the fields of religion and religious studies.

The present discussion sets as its starting point the question whether patriarchal dominance and gender hierarchy are part of the original Christian doctrine, or kerygma, or whether they are products of the society or culture in which Christianity emerged and developed. 


\section{The Mutual Influence between Society and Christianity and the Issue of Gender Hierarchy}

In the background of the topic of gender hierarchy we can, theologically speaking, primarily discern the question of reciprocal influence between society and Christianity. It is indisputable, in fact, that they have been shaping one another. The Christianity that enculturates into a certain environment adopts the characteristics of the culture in which it lives, and vice versa: a society in which the Christian tradition exists is shaped and enriched by it. How about the emergence of patriarchal supremacy? Is it characteristic of a society or is it part of natural law and thereby of Christianity? Was it Christianity that which had imprinted society with an even stronger mark of androcentrism or was it society and its patriarchal nature that led the development of Christianity in the direction of patriarchal androcentrism? These questions are of key importance to the issue of gender hierarchy from the standpoint of feminist theology, and to answer them we should first trace the origin of the patriarchal element. Christian theology has definitely contributed to the preservation of gender hierarchy in individual Christian Churches as well as in society. In fact, due to the marginalised status that women were given in institutionalised Christianity and its hierarchic systems, their voice was quite hushed up. This made women get used to being a passive link in the community they belonged to. The stories in which they took part were told by men, women's fate was determined by men. Their life stories became men's stories instead of women's own.

From this point of view, the idea of institutionalised Christianity being in this segment some sort of indirect violence against women does not appear altogether groundless, for especially in the past, women could not always express themselves as free subjects. Fearing women's power and authority, even Christianity often made them 'scapegoats' and subjected them to men. In his work Violence, Society and the Church, Gerald A. Arbuckle arrives at similar conclusions and points out the patriarchate as the oldest form of supremacy of one gender over another, that is, of men over women (Arbuckle, 2004). He believes that gender oppression stems from deeply rooted 'anti-women' prejudices preserved and strengthened throughout history. And the origin of all these prejudices and the patriarchate as an oppressive form of power is - in the opinion of anthropologists Edwin Ardener and Sherry Ortner - to be sought in 'men's feeling of loss of power and inferiority.' The two anthropologists argue the following thesis: in pre-modern cultures pregnancy and birth were understood as spheres of dangerous secret wrapped in a veil of mystery. 
DRUŠ. ISTRAŽ. ZAGREB GOD. 20 (2011),

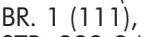

STR. 233-248

FURLAN, N.: INSTITUTIONALISED...
Despite or perhaps precisely because of this, the phenomena of pregnancy and birth aroused envy among men, as they made them feel helpless. The fact that men could 'seemingly' establish and determine the rights related to the offspring had to kneel down in front of the actual ability to 'create a life', which was outside men's power. Precisely because of their lack of this capability or power (to bear children), men pushed women aside and confined them to the 'wild sphere of nature,' while assigning other men the superior position in the area of social decision making and order. Women were thus ousted from the orderly social world of decision making and public social life, with their 'wild nature' representing the main obstacle and excuse for men to chase them away from this sphere. Consequently, women's position in society became marginal and only restricted to 'their primary function,' which was supposed to be ensuring procreation, that is, bearing offspring (Arbuckle, 2004, 39-40).

Just as Christianity during the enculturation into a certain environment adopts the characteristics of the culture which it lives in, the Church itself assumed numerous pre-modern customs in the process of its institutionalisation, such as the monarchic and patriarchal form of rule, and with time even prejudices against women that worked to the advantage of the patriarchate. We could say that, in the process of institutionalisation, the human element of the Church became more and more visible, at times even overshadowing its divine origin. The Church uncritically absorbed certain cultural characteristics and made them its own, becoming with time more a reflection of the influence of pre-modern society and its characteristics than of Jesus Christ's revolutionary new kerygma. Here, G. A. Arbuckle points out the case of acculturation of the patriarchal culture into the Church, which should instead have preserved and asserted the fundamental message of Jesus: to preserve life in love!

The institutionalised Church thus became patriarchal in its mentality as well as structure. Under Constantine the Church adopted the patriarchal form of rule and order of the Roman culture of the time, and thereby also the main principle of Roman law - pater familias - which was anything but favourable to the woman. According to Roman law, the woman was completely subordinate to her father or husband. She did not enjoy any legal protection or legal rights. Her status was marked and defined by the prejudicial belief in her physical and mental weakness. This same status was assigned to the woman within the Church and further aggravated in the 4th century. Many Early Church fathers characterised women as dangerous to men. "You are the devil's gateway!" said Tertullian about women in the 3rd century. Since the woman was 
DRUŠ. ISTRAŽ. ZAGREB GOD. 20 (2011), BR. 1 (111)

STR. 233-248

FURLAN, N. INSTITUTIONALISED.. considered impure in pre-modern cultures, this prejudice became the basis for excluding women from liturgical rituals. At the Synod of Laodicea in the 4th century it was decided that, due to their uncleanness, women could not go to the altar. In 829, the Synod of Paris 'added' the rule that women were prohibited from touching holy objects. In the same spirit, in the 12th century Gratian insisted that women be completely subject to their husbands, as they were not created in God's image (Arbuckle, 2004, 69-70). Men of patriarchal views were almost completely blinded by human haughtiness. Even in the case of the canonisation of Teresa of Avila, a church teacher who surprised the men of the cloth with unusual gifts and powers, the giftedness and extraordinariness of this woman were justified by the presumption that she had defeated her 'female nature.' Only because she had 'defeated her female nature' could she get closer to men. In other words, a woman could not succeed or do good deeds unless she 'adopted manliness' or the male principle of action. ${ }^{2}$

On the other hand, we are all the more surprised by the numerous ladies ${ }^{3}$ who resounded with their uniqueness and womanliness, perseverance and genuine selflessness in the light of Christ's joyous preaching, despite a less than encouraging atmosphere. They are the testimony that, in spite of a patriarchal climate, the wind of God's presence never stopped breezing through the Church. This fact was confirmed through a reconstruction of the mediaeval past by Tina Beattie, who maintains that the rich and varied world of the mediaeval Church was one of significant flourishing and social changes, as in her opinion women were not completely excluded from the currents of mediaeval society. Although living in a culture of (sometimes unrestrained) hatred towards women and frequent attempts to restrict their freedom, women - especially members of high society - were still able to get round the rules and create spaces from which it was possible to exert a permanent influence on society (Beattie, 2003, 23). Their existence also proves the erroneousness of the then patriarchal belief and numerous prejudices concerning women's inferiority, uncleanness and weakness. Although oppressed, numerous women throughout history strived for their voice in the Church to be heard.

With the emergence of a new ethos of life, which tends more and more towards the establishment of equality among people regardless of race, gender etc., women have been finding the Christian patriarchal model less and less suitable. The growing emancipation of women and the criticism directed at their social position in all the cultures of our time have been able to reach even the spheres of theology and the Church. As a response to the patriarchal androcentrism of Christianity, 
DRUŠ. ISTRAŽ. ZAGREB GOD. 20 (2011) BR. $1(111)$

STR. 233-248

FURLAN, N.: INSTITUTIONALISED... feminist theology ${ }^{4}$ emerged: a critical theology of liberation in which the new subject - the woman - 'has her say.' Feminist theologians primarily try to ask critical questions and examine the historical memory, recognising in it and reviving woman's value. The need for this remains, as the prejudice of female helplessness and inferiority is still deeply rooted in collective memory. This prejudice is also mentioned by Judy Chicago, who said: "All the institutions of our culture tell us through words, deeds, and - even worse - silence that we are insignificant. But our heritage is our power!" (Schüssler Fiorenza, 1983, 155).

The reconstruction of the past in the framework of the women's liberation movement thus tries to revive 'her-story,' that has been, in the opinion of feminist theologians, suppressed in the markedly masculine 'his-story' (Halkes, 1980, 163-164). Such a reconstruction is of utmost importance for the issue of gender equality within the Church. In fact, before the emergence of feminist theology there had been no serious questioning of the unfavourable interpretations of the texts from the Book of Genesis and other Biblical passages related to women. Consequently, negative interpretations controlled the Christian tradition for almost two thousand years (Hassan, 1994, 210). With the development of feminist theology, however, increasingly more women have noticed that the language of the Bible has quite a patriarchal tone. The Book bears, in fact, little trace of the feminine element, and in those rare cases where it can be found, it is nothing but a fleeting reflection of a woman as an object understood and presented through men's eyes.

On the part of the Catholic Church, a major turnabout, at least in theory, can be observed in the 1963 Pacem in Terris encyclical, in which Pope John XXIII described women taking on an active role in public as one of the signs of the times. It was in this very spirit that the Second Ecumenical Council of the Vatican was held, a council that many see as some sort of catalyst that would later enable and encourage the development of European feminist theology. This was the beginning of the shift in the women's issue. It should be emphasised, however, that the Second Ecumenical Council of the Vatican was unaware of the reflections about the woman and the women's issue that are evident today (Russell and Clarkson, 1996, 102).

In order to ascertain that patriarchal supremacy was characteristic of pre-modern society and the prejudices on which the society based its belief, and not of the preaching of Jesus Christ or the Christian tradition, we have to determine whether the gender hierarchy is ordained in the Bible and what Jesus Christ's attitude towards women was like. 


\section{Gender Equality and the Bible}

The Biblical accounts of the Creation and Fall in the Book of Genesis 1-3 are in terms of the position of women and gender hierarchy the most important writings of the Old Testament. The Biblical representation of the creation of the first human couple is based on two different sources, the Priestly source and the Yahwist source. Each gave origin to a different tradition, still the subject of eternal controversy among Christian theologians. "So God created man in his own image, in the image of God created he him; male and female created he them" (Gen 1:27). This passage does not indicate any supremacy of either gender; both are equal and "created in God's image" at the same time. Thus, the image of God is not reserved for the male gender only. Unlike Gen 1:27, the older, Gen 2:22 version, indicated subordination to the man, since the woman was created later "from the rib" of the man. "And the rib, which the Lord God had taken from man, made he a woman, and brought her unto the man" (Gen 2:22). These conflicting accounts are united in the Christian tradition. In the past, the Gen 2:22 account prevailed, as it better coincided with the ancient world in which Christianity developed and was pervaded by a patriarchal mindset (Drury, 1994, 32$-33)$.

The New Testament also reveals two views or traditions in complete contradiction. This is especially evident in the works attributed to the Apostle Paul, which reflect the viewpoint and influence of contemporary secular society, including as well as confirming the patriarchal values and consequently woman's subordination and inferiority, characteristic of the society of the time in which Paul lived and by which he was "in part" defined (Arbuckle, 2004, 69). Let us examine a few examples:

First example: "But every woman that prayeth or prophesieth with her head uncovered dishonoureth her head: for that is even all one as if she were shaven. For if the woman be not covered, let her also be shorn: but if it be a shame for a woman to be shorn or shaven, let her be covered. For a man indeed ought not to cover his head, forasmuch as he is the image and glory of God: but the woman is the glory of the man. For the man is not of the woman: but the woman of the man. Neither was the man created for the woman; but the woman for the man. For this cause ought the woman to have power on her head because of the angels" (1 Cor 11:5-10).

Second example: "Let your women keep silence in the churches: for it is not permitted unto them to speak; but they are commanded to be under obedience as also saith the law. And if they will learn any thing, let them ask their husbands 
DRUŠ. ISTRAŽ. ZAGREB GOD. 20 (2011) BR. 1 (111)

STR. 233-248

FURLAN, N.: INSTITUTIONALISED... at home: for it is a shame for women to speak in the church" (1 Cor 14:34-35).

The notes of the exegetes contain an explanation concerning these two passages, saying: "With his injunctions to the women to keep silent and not learn during public worship assembly, Paul does not pronounce an all time truth, but judges in the framework of his own notions and values of the patriarchal cultural climate, much like with his prescripts that women should keep their heads covered in churches and that it is inappropriate for them to wear short hair (cf. 11.6). Taking into account 11.5, it is highly probable that he himself did not take the prohibition in a general sense." Elizabeth Schüssler Fiorenza, informed by a feminist exegesis, sees Paul's words as a preventive measure with which he wished to protect the Christian community from "outside harm." In her opinion, Paul's restrictions of women's freedom and equality resulted from missionary inclinations, by which they allegedly tried to "satisfy" the current Roman social norm which forbade women to speak in public. Paul's intent was not, therefore, to impair or oppose the spiritual freedom and charismatic social endeavours of Christian women. One of the assumptions also maintains that Paul's restrictions only related to married women and widows. In any case, Schüssler sees in this the influence of the contemporary secular culture, which was unfavourable to women (Schüssler Fiorenza, 1983, 234).

Third example: "Wives, submit yourselves unto your own husbands, as unto the Lord. For the husband is the head of the wife, even as Christ is the head of the church: and he is the saviour of the body. Therefore as the church is subject unto Christ, so let the wives be to their own husbands in every thing. Husbands, love your wives, even as Christ also loved the church, and gave himself for it; that he might sanctify and cleanse it with the washing of water by the word. That he might present it to himself a glorious church, not having spot, or wrinkle, or any such thing; but that it should be holy and without blemish. So ought men to love their wives as their own bodies. He that loveth his wife loveth himself" (Eph 5:22-28).

This Biblical passage in particular, bearing the imprint of the patriarchal society of that time, served to subsequent generations as a basis for stereotypes on the "natural" subordination and submission of the wife to her husband. On the other hand, this particular Biblical passage holds the argument, which nevertheless speaks in favour of women, but was in the past unfortunately often missed or overlooked: despite displaying traces of patriarchal stance, this passage expresses a strong imperative of unselfish love. A love which as an allegory of Christ's love towards the Church, in addition to the "physical, 
DRUŠ. ISTRAŽ. ZAGREB GOD. 20 (2011), BR. 1 ( 1111$)$,

STR. 233-248

FURLAN, N. INSTITUTIONALISED.. secular" love, reflects above all the unselfish love of one who is willing to give their own life for the beloved person, in this case the wife. This allegory reminds and teaches us of what the bond and love between a husband and a wife should be like; it indicates unconditional love that should represent the foundation and framework of the husband-and-wife relationship. But instead of this aspect, the most frequently emphasised part was "Wives, submit yourselves unto your own husbands, as unto the Lord" (Eph 5:22), which helped strengthen the patriarchal authority of men over women. Because of that the essence of the idea contained in lines Eph 5:23-28 was disregarded. In fact, the passage - when interpreted and taken as a whole - expressed for Paul's times an extremely advanced view, as it did not place women in the subordinate position of "servants" in the negative sense of the word, but through the perspective of the contemporary mindset emphasised respect over domination, love over power and supremacy.

These three passages from the Bible manifest the cultural imprint on certain of Paul's works, which display traces of the contemporary patriarchal mindset and represent one of the two traditions that can be found in Paul's works. In addition to the tradition supporting patriarchal androcentrism, there is also the tradition that bears witness to and supports gender equality, as is evident from the following passages:

First example: "There is neither Jew nor Greek, there is neither bond nor free, there is neither male nor female: for ye are all one in Christ Jesus" (Gal 3:28). This passage represents not only the core of Paul's theology, but also the basic guideline of the early Christian missions (Schüssler Fiorenza, 1983, 199).

Second example: "I commend unto you Phebe our sister, which is a servant of the church which is at Cenchrea; That ye receive her in the Lord, as becometh saints, and that ye assist her in whatsoever business she hath need of you: for she hath been a succourer of many, and of myself also. Greet Priscilla and Aquila my helpers in Christ Jesus: Who have for my life laid down their own necks: unto whom not only I give thanks, but also all the churches of the Gentiles. Likewise greet the church that is in their house. Salute my well-beloved Epaenetus, who is the first fruits of Achaia unto Christ. Greet Mary, who bestowed much labour on us" (Rom 16:1-6).

These two passages are in complete contrast with the previous three. The double-edged nature of Paul's view of gender hierarchy and women's leadership was also observed by Schüssler, who said: "Paul's impact on women's leadership is double-edged. On the one hand he affirms Christian equality and freedom. He opens up a new independent lifestyle for women by encouraging them to remain free of the bondage 
DRUŠ. ISTRAŽ. ZAGREB GOD. 20 (2011) BR. 1 (111),

STR. 233-248

FURLAN, N.: INSTITUTIONALISED... of marriage. On the other hand, he subordinates women's behaviour in marriage and in the worship assembly to the interest of Christian mission" (Schüssler Fiorenza, 1983, 236). According to Schüssler, it was this very duality that enabled later generations to transplant the patriarchal hierarchy into the "new Christian community." The reconstructions of the history of the first Christian communities in fact reveal on the one hand the process of gradual "decline" of the patriarchal attitude, defeated by the Christian spirit of equality and solidarity, 5 while on the other, they point at a Christianity gradually assuming an increasingly patriarchal character, "enticed and conquered" by the patriarchal authorities (Schüssler Fiorenza, 1983, 80). In this context, taking into account the opinions of various historians, the feminist theologian M. E. Hunt wonders: "How could Catholicism in the first centuries have changed from a religious tradition in which women originally had their place, to a religious tradition in which they were segregated, then practically shut off, and nowadays finally gained a considerable pastoral and intellectual influence?" (Hunt, 1999, 366).

Throughout the Biblical texts it is possible to observe the duality of tradition. Both in the texts of the Old and New Testament two views coexist: the patriarchal and that of gender equality. In the past, the Church frequently preferred using the patriarchal Biblical texts to establish and maintain the patriarchal system, while disregarding the texts testifying to the equality of the two genders. But nevertheless, the spirit of equality and love, characteristic of God's word and the gospel, was not drowned out.

It was precisely this spirit of equality and solidarity that persuaded women to join Jesus as the first non-Jews.

\section{Jesus' Attitude towars Women}

Jesus' movement and with it the beginnings of Christianity will be easier to understand if we try to recall the Jewish patriarchal-invested society of the time in which Jesus preached. His activity should be understood in the sense of a Jewish modernisation movement. This offers a new view and understanding of the then Jewish society organised on patriarchal standards and, most importantly, does not reject Jewish practice and values. By placing Jesus in the social-historical context of his time we can better understand the importance of his 'new' modernising movement for Jewish society.

In Jesus' times, women were regarded as second-class Jews and as such excluded from religious practice. The society had assigned them a position similar to that of slaves. In this sense, Jesus could be seen as a revolutionary of equality (Arbuckle, $2004,43)$. Indeed, in a society which sooner despised women 
DRUŠ. ISTRAŽ. ZAGREB GOD. 20 (2011), BR. 1 (111)

STR. 233-248

FURLAN, N. INSTITUTIONALISED.. than respected them, Jesus - as Pope John Paul II said in his Letter to Women - 'transcended the established norms of his own culture and treated women with openness, respect, acceptance and tenderness. In this way he honoured the dignity which women have always possessed according to God's plan and in his love' (John Paul II, 1988, 803). In this divine love is found the origin of her equality with her husband, 'for it is in this unconditional God's love that the genuine human value of a husband and a wife lies, not in external social and psychological facts, (MD, 1988, 30)' stressed the pope in his apostolic letter titled Mulieris dignitatem.

Not a single thing can be detected in Jesus' attitude towards women that would reflect discrimination against them, though such was common during his period. In fact, the very opposite is true: his words and actions always expressed the respect and honour that women deserve. The way Jesus addressed women, talked and behaved toward them was in light of the prevailing habits of that time something completely 'new.' Jesus of Nazareth returned to women the dignity they had been denied and that had been taken away by the patriarchal authorities. Jesus strived to recall women's dignity and revive respect for them in people's minds. By accepting respect for women as the contents of the gospel and kerygma he had come into the world for, he restores it and gradually awakens it in the minds of the people. In this sense, Christ did everything he could to help women rediscover their subjectivity and dignity in his teachings and behaviour, in the framework of the customs and social circumstances of the time. Not infrequently was this cause for astonishment in the then society (MD, 1988, 26-29).

Although Jesus' attitude towards women is understood completely in the light of equality and dignity, Snežna Vrečko believes that the social and psychological facts of the patriarchal world "had - unfortunately in Church as well - a great importance, often even greater than the dignity that Jesus acknowledged to women. This prevailing social aspect can, in her opinion, be sensed in the Gospels as well" (Vrečko, 2001, 2).

Indeed, the Gospels talk about miracles that Jesus performed to the benefit of women and men alike. We can witness wonderful encounters between Jesus and women, who feel liberated in his presence. Jesus talks with them about issues that were not usually discussed with women in those times. Jesus appreciates their opinion and sets it as an example or even a starting point for his preaching. Much more often than Jewish teachers he uses female figures in his parables: a woman kneading dough, a woman looking for a lost drachma, a woman getting a judge to pass a just sentence with her perseverance, a woman donating her last two pennies to the 
DRUŠ. ISTRAŽ. ZAGREB GOD. 20 (2011) BR. 1 (111)

STR. $233-248$

FURLAN, N.: INSTITUTIONALISED...

\section{CONCLUSION}

temple treasury, etc. There are many cases in which Jesus protected women against the hardheartedness of men by renewing old rules: by forbidding a husband to send his wife away (cf. Mt 19, 1-9); by condemning divorce and polygamy he introduced a new evaluation of the woman into the ancient world. There are also many cases in which Jesus ascribed women the same position as men, defining them as daughters of Abraham (cf. Lk 13, 10-17). Where he works, the woman's position in society changes: Mary listens to what he says, just like his disciples, and even Martha is invited to choose the good part for a woman. However, in the opinion of Vrečko, an accurate reading of the Gospels shows the reports on women to be still surprisingly reserved.

Feminist theologians recognise the silence in this very point and try to access the space in which the woman is wrapped in silence, yet present, via the door opened by the reports on the relationship between Jesus and women. In the silence surrounding the mention of women in Gospels, they see the heritage of the times entered by Jesus. But on few occasions women do step out of the silence and denial, and it is possible to infer from these moments that they were much more present in Jesus' life and action than the Gospels explicitly relate.

"How could it come about that Christianity, which in its essence proclaims the salvation of all people, so quickly turned into a religion that through the abuse of power and a destructive tendency to prevail over the woman represents the violence that robs the woman and her sexuality of the dignity as an equal God's creature?"

Patriarchal belief found in Christianity a fertile soil for spreading gender hierarchy, based mainly on three fundamental presumptions: firstly, that the first being created by God was a man and not a woman, as the prevailing conviction was that the woman was created from the man's rib, and was thus, ontologically speaking, something derived and secondary. Secondly, that the one mainly responsible for the expulsion from the Garden of Eden was the woman, who committed the 'original sin' and that consequently 'all the daughters of Eve' should be looked upon with hatred, distrust and contempt. Thirdly, that the woman was not only created from the man, but also for the man, which gave her existence only an instrumental rather than a fundamental value. We thus speak about three theological questions which under the influence of the cultural-sociological conditionality of the time characterised and marked the fate of the female sex for 
DRUŠ. ISTRAŽ. ZAGREB GOD. 20 (2011), BR. 1 (111)

STR. 233-248

FURLAN, N. INSTITUTIONALISED.. almost two millennia: How was the woman created? Was she responsible for the original sin of the first human/man? What was the woman created for? (Hassan, 1994, 211)

The issue of gender hierarchy in Christianity thus depends on the Biblical passage we choose, on its interpretation, but mostly on the consideration of the context in which the Bible was written. Particularly important is also the tradition that the interpretations of the Bible are based on and derived from. As we have seen, the Bible offers two traditions: the patriarchal and that of gender equality. In this respect, Jesus is the 'revolutionary' of all times, as he teaches to choose love and compassion, a life in the light of equal solidarity, instead of domination and power. This principle of equality was a typical and 'recognisable' sign of the early Christian Churches, which were permeated by Jesus' spirit of a Church of equal brothers and sisters united in the spirit of God's kingdom of mutual respect and equality. As a 'friend of all women' Jesus established a 'new' ethos in the sense of feminisation and ethicisation of the world. Instead of a power game in which certain groups oppress others, Jesus sets human equality as basic. Human beings, men and women, thus serve and create life, defending it when it is in danger (Küng, 2001, 3-4).

In this sense, the original Christian doctrine not only preaches and protects gender equality or life in equal respect and solidarity, but sets it as an imperative and the core of all interpersonal relationships. It fights in non-aggressive ways against patriarchal principles, choosing love instead and putting to the fore the equality of all human beings. Christianity has always taught that Christ's salvation is offered to all people regardless of sex, race, age, class or nationality. The words of St. Paul the Apostle in Gal 3, 27-28 thus represent the core and the foundation integrating the imperative of equality of all people into the Christian ethos.

Nevertheless, in the process of institutionalisation of the Christian Church, Catholic and Orthodox in particular, 'the equality ethos' was replaced by a tendency for power and domination of men over women. The Church gradually absorbed patriarchal principles into its order and with it the 'power and domination' over women. Just as culture with its patriarchal character marked the Church, on several occasions throughout history the Church helped consolidate the patriarchal ideology of the culture in which it was developing.

${ }^{1}$ In addition to other Christian Churches, the term 'Church' in the present text refers primarily to the Catholic Church.

2 To a great extent, this is still valid today: the woman is 'secretly' expected to assume the male principle of action if she wants to be successful in society. 
DRUŠ. ISTRAŽ. ZAGREB GOD. 20 (2011), BR. 1 (111)

STR. 233-248

FURLAN, N.: INSTITUTIONALISED...
${ }^{3}$ Despite incomplete historical records, there exist numerous testimonies of exceptional women. In her work dating from 1415, The Book of the City of Ladies, Christine de Pizan enumerates an impressive series of important women active within the Church or in secular life (Pizan, 1999). Régine Pernoud, too, offers numerous cases of meritorious women from the Middle Ages (Pernoud, 2003, 103-117).

${ }^{4}$ Feminist theology, according to Alfred T. Hennelly, which "is one of the nine categories of the liberation theology", has spread from the USA throughout the world (Hennelly, 1990, 150). In separate developmental periods of feminist theology, different types of feminist theology have formed: (1.) The revolutionary feminist theology (we can say that the founder of this theology is a fighter for women's rights Matilda Joslyn Gage (1826-1893), Susan B. Anthony and Elizabeth Cady Stanton who publish The Woman's Bible (in 1895) with a group of American women. It is a collection of biblical texts which talk about a woman and the interpretations in accordance with the spirit of their selfunderstanding at that time). (2.) The reformist Christian feminist theology; reconstructive Christian feminist theology. This diversity is gaining its expression in various essays of feminist theology. If the "woman's experience" is a deciding measure for the feminist theology, the authors are thus distinguished from a bigger or lesser affiliation to women's movement on one side, from a bigger or lesser eclectic belonging on the other and from a less severe critique of the "traditional" theology and the Church. The most severe division of the feminist theology is: "inside-Christian" and "post-Christian or non-Christian" feminist theology. The first and the main group stays inside the biblical-Christian tradition as a prophetic critique of the society and above all the Church. (For more detailed description of Christian feminist theology see: Nadja Furlan (2006), Manjkajoče rebro, Koper: Annales.)

5 The first Christian communities in the pre-Pauline era and at the time of Apostle Paul were in fact characterised by a typical spirit of equality and mutual solidarity. The position of women in this period is supposed to have been almost in everything equal to the position enjoyed by men. In the first Christian churches women administered the Holy Communion, preached God's word, held various managing functions and did missionary work. Women thus contributed considerably to the establishment of the early Church (Arbuckle, 2004, 70). H. Küng also underlines the spirit of equality, which was a characteristic, 'recognisable' sign of the first Christian Churches (Küng, 2001, 3).

Arbuckle, G. A. (2004), Violence, Society and the Church: A Cultural Approach, Minnesota: Liturgical Press, Collegeville.

Beattie, T. (2003), Woman (New Century Theology), New York: Continuum. Drury, C. (1994), Christianity. In: J. Holm and J. Bowker (eds.), Women in Religion, London: Printer.

Franzmann, M. (2000), Women and Religion, New York: Oxford University Press.

Halkes, C. (1980), Primo bilancio della teologia femminista. In: M. Hunt and R. Gibellini (eds.), La sfida del femminismo alla teologia, Brescia. 
DRUŠ. ISTRAŽ. ZAGREB GOD. 20 (2011), BR. 1 (111)

STR. 233-248

FURLAN, $N$ INSTITUTIONALISED...
Hassan, R. (1994), Frauen im Islam und im Christentum. Concilium, 30 (3): 209-218.

Hennelly, A. T. (1990), Liberation Theologies, A Documentary History, New York: Orbis Books.

Hunt, M. E. (1999), Wir Frauen sind Kirche. Concilium, 35 (3): 366-376.

John Paul II (August 15, 1988), Apostolsko pismo o dostojanstvu žene, Mulieris dignitatem. In: AAS 80 (1988) 1653-1729, translated into English, CD 40, Družina, Ljubljana 1989.

Küng, H. (2001), Women in Christianity, New York: Continuum.

Pernoud, R. (2003), Nehajmo že s tem srednjim vekom, Ljubljana: Družina. Pizan, C. (1999), Mesto dam, Ljubljana: Delta.

Russell, L. M. and Clarkson, J. S. (1996), Dictionary of Feminist Theologies, Kentucky: Westminster John Knox Press.

Schüssler Fiorenza, E. (1983), In Memory of Her, New York: Crossroad. Sorge, E. (1988), Religion und Frau. Weibliche Spiritualität im Christentum, Stuttgart: Kohehammer.

Sveto Pismo, Slovenski standardni prevod iz izvirnih jezikov (1996), Ljubljana: Svetopisemska družba Slovenije.

The Bible, New Revised Standard Version with the Apocrypha (2007), Massachusetts: Hendrickson Publishers, Inc.

Vrečko, S. (2001), Jezusov odnos do ženske. Tretji dan (4): 2-7.

\section{Institucionalizirano kršćanstvo i pitanje hijerarhije rodova}

Nadja FURLAN

Znanstveno-istraživački centar, Koper

Članak iz perspektive feminističke teologije raspravlja o pitanju pojave i nazočnosti patrijarhalnosti, hijerarhije među rodovima i nejednakopravne i neravnomjerne raspodjele moći među rodovima unutar kršćanstva. Prije svega postavlja pitanje je li nadvlast vlastita i obvezna u kršćanskoj tradiciji ili se razvijala i ojačala kroz institucionalizaciju kršćanstva. U zapadnom svijetu, koji se razvijao pod utjecajem kršćanstva, moguće je otkriti sve više kritičnih pitanja u odnosu na hijerarhiju rodova unutar kršćanskih Crkava, s naglaskom na Katoličkoj crkvi. Patrijarhalna obojenost crkvenog uređenja dovedena je u pitanje i pod povećalo. Članak uz pomoć znanstvene metodologiie hermeneutičkoga ključa feminističke teologije nastoji pokazati podrijetlo patrijarhalnog andocentrizma i nejednaku i neravnopravnu evaluaciju obaju rodova. Rezultati prikazanih rasprava potvrđuju pretpostavku da je Katolička crkva u procesu institucionalizacije usvojila patrijarhalni pečat kulture u kojoi se razvijala i pretpostavku da kršćanstvo u svojem nauku stavlja jak imperativ jednake vrijednosti i ravnopravnosti 
DRUŠ. ISTRAŽ. ZAGREB GOD. 20 (2011)

BR. 1 (111)

STR. 233-248

FURLAN, N.: INSTITUTIONALISED... rodova koja je utemeljena u osobi Isusa Krista i njegovu odnosu prema ženama kao i u Bibliji.

Ključne riječi: hijerarhija među rodovima, ravnopravnost rodova i Biblija, institucionalizacija kršćanstva, patrijarhalizacija crkve i kršćanstva, feministička teologija

\section{Institutionalisiertes Christentum und die Frage der Geschlechterhierarchie}

Nadja FURLAN

Wissenschaftliches Forschungszentrum, Koper

Aus der Perspektive einer feministischen Theologie werden das Phänomen des Patriarchats, die Geschlechterhierarchie sowie die ungleichberechtigte und ungleichmäßige

Machtverteilung auf die Geschlechter innerhalb des Christentums erörtert. Die Verfasserin stellt zuallererst die Frage, ob das Bestehen einer Über-Macht dem Christentum eigen und ob sie obligat ist, oder ob sie sich aufgrund der Institutionalisierung des Christentums entwickelte und stärker wurde. In der vom Christentum geprägten westlichen Welt ergeben sich immer mehr kritische Fragen in Bezug auf die Geschlechterhierarchie innerhalb der christlichen Kirchen, zumal in der katholischen Kirche. Das in der kirchlichen Ordnung bestehende Patriarchat wird in Frage gestellt. Die Verfasserin geht methodologisch so vor, dass sie sich des hermeneutischen Schlüssels der feministischen Theologie bedient, um auf den Ursprung des patriarchalen Androzentrismus hinzuweisen sowie auf die ungleiche und ungleichberechtigte Stellung der Geschlechter. Das Ergebnis der Erörterung bestätigt die Annahme, dass die katholische Kirche im Prozess ihrer Institutionalisierung die patriarchalisch geprägte Kultur, in der sie sich entwickelte, übernommen hat. Ebenso bestätigt wird die Annahme, dass in der christlichen Lehre ein starker Imperativ nach Gleichwertigkeit und Gleichberechtigung von Mann und Frau existiert. Dieser Imperativ ist in der Person Jesu Christi und seiner Einstellung zur Frau verankert wie auch in der Bibel selbst.

Schlüsselbegriffe: Geschlechterhierarchie, Gleichberechtigung von Mann und Frau und die Bibel, Institutionalisierung des Christentums, Patriarchalisierung von Kirche und Christentum, feministische Theologie 